УДК 780.643.2.082.4 : [785.7 : 780.614 .3$]$ : 78.071 .1 (44)

DOI 10.34064/khnum1-5407

\title{
Чуріков В. В.
}

ORSID 0000-0003-3447-4434

Харківський національний університет мистецтв імені І. П. Котляревського, 61003, майдан Конституиіï, 11/13, м. Харків, Украӥна

\section{Концерт для саксофона та струнного оркестру П.-М. Дюбуа: методичні настанови до виконання}

АНОТАЦІЯ - Чуріков В. В. Концерт для саксофона та струнного оркестру П.-М. Дюбуа: методичні настанови до виконання. - Статтю присвячено творчості французького композитора П.-М. Дюбуа, зокрема, виконавському аналізу його Концерту для саксофона. Підготовка методичних настанов до виконавського прочитання твору дала підставу до таких висновків: композитор враховував інструментальну специфіку та, синтезуючи різностильові комплекси, склав оригінальну авторську концепцію. В ній збережено традиції програмності, кольоровості жанрової палітри, є збагачення стилістики та вільне ставлення до композиційної структури концерту (йдеться про співвідношення розділів, масштабів, розташування каденції, вільно 
трактованої сонатності та пріоритетності варіативного розвитку тематизму). В ракурсі стильових витоків очевидними є орієнтири композитора на художні засади неокласицизму, імпресіонізму та експресіонізму (стильові алюзії на стилі Д. Шостаковича, С. Рахманінова, П. Гіндеміта, М. Равеля). Така «багатовекторність» стилю Концерту зумовлює багатоплановість стилістичного виміру твору та ставить перед виконавцем завдання диференціації виразних засобів - перш за все, тембрової палітри та артикуляційної техніки. - Ключові слова: конщерт для саксофона, виконавські засоби виразності, артикуляиійна техніка на саксофоні, П.-М. Дюбуа.

\section{АННОТАЦИЯ — Чуриков В. В. Концерт для саксофона и струнного} оркестра П.-М. Дюбуа: методические указания к исполнению. - Статья посвящена творчеству французского композитора П.-М. Дюбуа, в частности, исполнительский анализ его Концерта для саксофона. Подготовка методических указаний к исполнительскому прочтению произведения дала основание для следующих выводов: композитор учитывал инструментальную специфику и, синтезируя различные стилевые комплексы, составил оригинальную авторскую концепцию. В ней сохранены традиции программности, красочность жанровой палитры, обогащение стилистики и свободное отношение к композиционной структуре концерта (речь идёт о соотношении разделов, масштабов, расположении каденции, свободно трактуемой сонатности и приоритетности вариативного развития тематизма). В ракурсе стилевых истоков очевидны ориентиры композитора на художественные принципы неоклассицизма, импрессионизма и экспрессионизма (стилевые аллюзии в стиле Д. Шостаковича, С. Рахманинова, П. Хиндемита, М. Равеля). Такая «многовекторность» стиля Концерта обуславливает многоплановость стилистики произведения и ставит перед исполнителем задачу дифференциации выразительных средств - прежде всего, тембровой палитры и артикуляционной техники. - Ключевые слова: конщерт для саксофона, исполнительские средства выразительности, артикуляционная техника на саксофоне, П.-М. Дюбуа.

ABSTRACT - Churikov V. V. Concerto for saxophone and string orchestra by P.-M. Dubois: guidelines for performance.

- Statement of the problem. Creativity for saxophone by the French composer Pierre-Max Dubois (1930-1995) reflects in its sound palette many 
style tendencies of music art of the twentieth century. A student of D. Milhaud, he inherited from his teacher the desire for vivid character and imagery of music, which were achieved by various artistic possibilities of modern musical styles and trends. For the saxophone, he wrote such compositions as Characteristic pieces in the form of a suite, Quartet, Divertissement, Sonata and Concerto for saxophone and string orchestra which is quite relevant for the repertoire of the modern saxophonist. Taking into account specific features of the author's style of P. Dubois, the performer faces the problem of mastering a number of technical and artistic expressive techniques aimed at revealing the figurative content of the piece. For a contemporary performer, the awareness of style components of P. Dubois' music, which make up the logic of the performance interpretation, is of particular importance. These are the main aspects of work at this composition in the class of saxophone.

Analysis of recent publications on the topic. Saxophone performance is considered in many publications, including those written by the author of this paper. However, there are very few works related to the study of P.-M. Dubois' creative work, and all of them are bibliographic or encyclopedic in nature. Therefore, the analysis of compositions by P.-M. Dubois seems relevant.

The purpose of the study is to develop methodology guidelines on search for performance interpretation of Concerto for Saxophone and String Orchestra by P. Dubois.

Presentation of the main research material. The Concerto for Saxophone and String Orchestra by P. Dubois was written in 1956 and was a striking embodiment of the instrumental style of the French composer. Adhering generally to traditional ideas about instrumental genres, P. Dubois greatly expands the sound palette of his works and develops the expressive capabilities of the saxophone. As a student of the famous and one of the most extravagant representatives of the French "Group of Six" - D. Milhaud, P. Dubois in many ways inherits the principle of distinctness of musical language and bright, expressive musical and artistic imagery.

P. Dubois' concerto is a traditional three-part cycle, built on the principle of contrasting extreme fast and medium slow parts, which in the overall contexture of the composition are very different in their imaginative content and musical language. Highlighting the stylistic origins of music of the Concerto, the composer is obviously focused on artistic principles of such musical directions as neoclassicism, impressionism-symbolism and expressionism. 
Conclusions of the study. From the viewpoint of performance, works for saxophone by P. Dubois have undoubted merits. They are instrumental in nature, written in the light of instrumental specificity, though not without technical and imaginary difficulties. Summarizing the analysis of the Concerto for the saxophone by P. Dubois, it can be argued that this piece clearly fits into the artistic context of the development of French music in the second half of the twentieth century, since it reflects the process of synthesizing various style complexes in the original author's concept.

1. Concerto for Saxophone and String Orchestra by P. Dubois is an original interpretation of the concerto genre in the context of French music of the second half of the twentieth century. Preserving national traditions of instrumental thinking - programmability, genre, beauty of the timbre palette - P. Dubois enriches the musical language of his work significantly and freely interprets the compositional structure of the concerto (the ratio of form sections, their scales, cadence at the very beginning of the sonata allegro, "removed" thematic contrast and a departure from conflict dramaturgy). On the whole, we can speak of a shift from the sonata form and priorities of the variative development of the musical thematism.

2. In identifying the stylistic origins of the Concert's music, the composer's focus on artistic principles of such musical directions as neoclassicism, impressionism-symbolism and expressionism are evident. Moreover, each of these style complexes is as if personified in a specific author's "manner", causing reminiscence with the music of D. Shostakovich, S. Rachmaninov, P. Hindemith, M. Ravel. Such a "multicomponibility" of the Concerto style introduces the multifaceted nature of the musical language of the piece and assigns the performer the task of differentiating expressive means - mainly the timbre palette and articulation technique.

The prospect of further study of the topic is related to the performance analysis of other works by P. Dubois for saxophone, comparison of interpretations made by contemporary prominent artists. - Key words: concerto for saxophone, performing means of expression, articulation technique on saxophone, P. Dubois.

Постановка проблеми. Твори для саксофона французького композитора П. Дюбуа (1930-1995) відображають у своїй звуковій палітрі багатостильові тенденції музичного мистецтва XX століття. 
Учень Д. Мійо, П. Дюбуа успадкував від свого вчителя прагнення до яскравої характерності та образності музики, які досягалися різними художніми засобами тогочасних музичних стилів і напрямків. П’єр-Макс Дюбуа, відомий, в першу чергу, як автор великої кількості творів для духових інструментів, а його музика для різних інструментальних складів, твори для флейти, кларнета, тромбона, фагота $є$ популярними серед сучасних виконавців. Для саксофона ним написані такі твори, як Характерні п’єси у формі сюїти, Квартет, Дивертисмент, Соната і Концерт для саксофона і струнного оркестру. Твори П. Дюбуа доволі актуальні в репертуарі сучасного саксофоніста, а твір, який ми аналізуємо, багато в чому відображає стильові тенденції музичного мистецтва XX століття, демонструючи оригінальність авторського задуму в подоланні усталених канонів жанру інструментального концерту. 3 огляду на специфічні особливості авторського стилю П. Дюбуа, виконавець стикається з проблемою опанування цілої низки технічних і художньо-виражальних прийомів, спрямованих на розкриття образного змісту твору. Для сучасного виконавця особливе значення має розуміння стильових складників музики П. Дюбуа, які формують логіку виконавської інтерпретації. Цілком природно, що саме цьому приділяється основна увага при роботі над названим твором у класі.

Аналіз останніх публікацій за темою. Виконавству на саксофоні присвячено безліч публікацій [1; 3-6], зокрема, - автора пропонованої статті [7; 8]. Що стосується досліджень творчості П. Дюбуа, то їх вкрай мало й усі вони - бібліографічного або енциклопедичного характеру [9]. Тому ретельний музикознавчий аналіз творів П.-М. Дюбуа видається вкрай актуальним.

Мета даного дослідження - сформулювати методичні настанови до виконавського прочитання Концерту для саксофона та струнного оркестру П. Дюбуа.

Викладення основного матеріалу дослідження. Концертний жанр для саксофона, представлений у XX столітті в усьому розмаїтті існуючих типів. Так, до першої половини століття відносяться: Концерт для саксофона-альта А. Глазунова (1934), «Концертштюк» П. Гіндеміта (1933), Концерт для саксофона-альта Е. Ларсена (1934), Концерт П. Велонезе (1934), «Камерне концертино» Ж. Ібера, 
Концерт П. Крестона (1941). Концерт для саксофона і струнного оркестру П. Дюбуа був написаний 1956 року і став яскравим втіленням інструментального стилю французького композитора. Дотримуючись в цілому традиційних уявлень про інструментальні жанри, П. Дюбуа значно розширює звукову палітру своїх творів і розкриває виразні можливості саксофона. Будучи учнем знаменитого й одного 3 найбільш екстравагантних представників французької групи «Шести»Д. Мійо - П. Дюбуа багато в чому успадковує принцип характерності музичної мови та яскравої, виразної музично-художньої образності.

Концерт П. Дюбуа являє собою традиційний цикл із трьох частин, збудований за принципом контрастування крайніх швидких та середньої повільної частини, які в загальній композиції твору суттево розрізняються за своїм образним наповненням і музичною мовою. Виокремлюючи стильові витоки музики Концерту, ми виявлясмо очевидну зорієнтованість композитора на художні засади таких музичних напрямів як неокласицизм, імпресіонізм, символізм та експресіонізм. При чому кожен із зазначених стилів немов персоніфікується в конкретній авторській «манері», викликаючи ремінісценції з музикою Д. Шостаковича, С. Рахманінова, П. Гіндеміта, М. Равеля. Подібна стильова «багатовекторність» Концерту зумовлює багатоплановість музичної мови твору і ставить перед виконавцем завдання диференціації виразних засобів.

Частина 1. Lento espressivo - Allegro. Тривалість 7:06.

Перша частина Концерту композиційно будується за принципом сонатного алегро, проте П. Дюбуа доволі вільно трактує класичну форму: це позначається і в контрастності основного тематизму, і в співвідношенні окремих розділів, і у «взаємодії» партії соло інструмента $з$ оркестром. Загальний колорит та інтонаційний характер музики першої частини викликає асоціації з музичним стилем П. Гіндеміта і Д. Шостаковича - та ж загострена характерність основних тем, принципова монологічність у викладі партії саксофона, динаміка та гнучкість ладотонального й гармонійного розгортання музичного матеріалу.

Вже початкова тема вступу першої частини налаштовує на експресивну виразність монологу саксофона solo: імпровізаційний ви- 
клад 3 характерними альтераціями і хроматизмами, фігуративне інтонаційне розгортання 3 «перериваним диханням» - паузами на початку кожного такту. Всі ці «ознаки експресії» викликають в пам'яті інструментальні монологи в музиці Д. Шостаковича, які уможливлюють занурення у внутрішній світ героя та зосередженість течії думки. Членування паузами «нескінченного» інтонаційного потоку в подальшому розвитку партії саксофона (від т. 4) надає темі ознак декламаційності, мовного висловлювання, забарвленого емоційним станом схвильованості та напруги.

Ця частина має незвичайну для концерту структуру, яка складається 3 двох розділів, розділених між собою каденцією. Повільний вступ в темпі ઈ 58, який саксофон виконує без супроводу. За деякими ознаками це нагадує каденцію, оскільки йдеться про соло, однак, характер музики демонструє дещо інше семантичне навантаження даного матеріалу.

У дисертаційному дослідженні А. Понькіної [6] дається детальна класифікація типів каденцій, які зустрічаються в сонатах для саксофона композиторів другої половини XX століття. Це дві основні категорії - каденція-розділ (каденція-інтермедія, каденція-інтерлюдія (прелюдія), каденція-розробка, каденція-постлюдія, каденція-зв'язка, каденція-рефрен,) і каденція-частина (два типи - виконують функцію зв'язки-розробки та функцію постлюдії). Використовуючи цю класифікацію, вступ до Першої частини концерту можна визначити як «квазі-каденцію». У плані фразування вступ містить короткий однотактовий мотив 3 чотирьох угруповань шістнадцятих 3 шістнадцятою паузою на початку, який утворює секвенції з трьох ланок і далі зазнає розвитку. В інтервальному відношенні для даного мотиву характерні стрибки на широкі інтервали: велику й малу септими, октаву, малу нону. У такті 4 цифри 1 відбувається повторення експозиції мотиву, вступають струнні інструменти в мінімальному динамічному нюансі, поступово посилюючись в динаміці. Розвиваючи тему, композитор у партії саксофона застосовує велику кількість секвенційних оборотів. У такті 5 цифри 2 оркестр замовкає, і саксофон виконує тривалу каденцію, що відрізняється помірною віртуозністю та цільними блоками секвенцій-пасажів. Це, наприклад, спадний пасаж 
секстолями шістнадцятими від ноти «фа» третьої октави, далі від ноти «ре-дієз» і так далі. У каденції присутні чергування пасажів від нот «до» і «до-дієз» першої октави, а потім з'являється нова тема мелодія пісенного складу, що має схожість 3 темою вступу опери М. Мусоргського «Борис Годунов». Ця тема присутня і в наступному розділі. Завершується каденція віртуозними пасажами по діатонічних терціях у висхідному напрямку, які потім змінюють напрямок і розподіл тривалостей. 3 огляду на розташування та тип матеріалу, викладений в каденції, за класифікацією А. Понькіної дану каденцію ми віднесемо до «каденції-інтермедії». Ця каденція виконує функцію смислового розмежування двох музичних блоків Першої частини.

Друге проведення вступної теми набуває ознак ще більшої тривожності за рахунок «повзучих» басів низьких струнних. Насичене альтерірованими гармоніями подальше розгортання теми призводить до досить незвичайної кульмінації - каденції соліста, яку композитор розташовує не в кінці першої частини (традиційний варіант сонатного алегро інструментального концерту), а на самому початку - перед викладом головної партії. Таким чином підкреслюється значимість заявленої на початку музичної образності - експресивного монологу соліста - що й формує весь стильовий образ і характер подальшого музичного матеріалу.

Після каденції слідує розділ 2 - Allegro, що представляє абсолютно інший характер викладу музичного матеріалу. Головна партія являє собою гранично контрастний матеріал по відношенню до теми вступу - це танцювальна тема з гострою виразною ритмікою, підкресленою стаккатним штрихом. Подібну характеристику музичного тематизму часто можна зустріти в інструментальних темах Д. Шостаковича, що втілюють образи «злих» скерцо і фантастичних видінь. Масштаби головної партії Концерту також різко контрастують 3 розгорнутою темою вступу - всього 20 тактів. Одним 3 найяскравіших та акцентованих композитором контрастів між головною партією і вступною темою є фактурний виклад: верховенство мелодико-інтонаційного розгортання на тлі скупих, але терпких і островиразних гармоній оркестру, а ще - чітка графічність і «примітивізм» дводольного розміру. 
Від цифри 3 змінюється розмір з 4/4 на 2/4 і темп зростає до $\$ 182$. Звучить нова тема - скерцо, тривалістю 8 тактів, характер якої передається композитором за допомогою штриха стаккато, інтервальних стрибків вниз на малу сексту й чисту квінту. Розділи першої частини концерту побудовані за контрастом: якщо в першому розділі домінує плавність, безперервність фразування, «легатність», співучість, то в другому розділі використовуються протилежні виразні засоби і створюється танцювальний, скерцозний настрій.

Побічна партія (ц. 5) також звернена до мелодійного стилю «зразка» Д. Шостаковича: діатонічна мелодія широкого дихання саксофона на тлі хроматизованої фігурації, ефект подібності зі стилем російського композитора посилений і дублюванням мелодії октавним діапазоном регістрів. Третє проведення теми в оркестрі змінює образне наповнення музики, оскільки в партії саксофона з'являються неспокійні декламаційні інтонації, співзвучні темі вступу.

Перед цифрою 6 проводиться друга тема розділу, що пов'язана 3 пісенними джерелами, і яка вже була представлена в каденції. Вона позначена тональною нестійкістю й модулює в соль-мінор, а потім в ля-мінор (тональності визначені по нотах партії саксофона-альта, стрій якого - мі-бемоль). Тема триває 2 такти й різко контрастує 3 першою темою цього розділу. Щоб підкреслити це протиставлення, автор відразу після проведення другої теми повторює першу, але скорочену вдвічі.

У короткому розробочному розділі (від ц. 7) у соліста з'являються ритм та інтонації головної партії, які набувають ще більшої характерності - йдеться про колорит гармонійного розвитку, зіставлення далеких тональностей, перекличка коротких фраз саксофона та оркестру. Гостра ритміка і свобода інтонаційного розвитку вимагають від виконавця гранично чіткої артикуляції та чіткого видобування кожного звуку, уваги до штрихів. Виразною особливістю саксофонної партії тут є, перш за все, лаконічність фразування й декламаційність музичного тематизму, яка уподібнює музичний виклад мовному вислову. У репризі співвідношення головної та побічної партій зберігається, але динамізується загальний тонус розвитку за рахунок яскравого тонально-гармонічного колориту. Перша тема не проводиться в іiї оригінальному вигляді, при- 
сутні тільки окремі фрагменти з неї. Взагалі, композиторському стилю П. Дюбуа притаманне дроблення фраз, мотивів на сегменти та подальше їх комбінування, а також контрастне протиставлення.

До кінця першої частини музичний матеріал побудований з окремих сегментів всіх тем 3 двох розділів. Завершується перша частина низхідним пасажем штрихом стаккато на IV ступені головної тональності даної частини (фа-дієз-мінору). Слід звернути увагу на загальну, характерну для всього концерту тональну нестійкість. Зміна тональності може відбуватися як по кварто-квінтовому колу, так і в тональності далекого ступеня споріднення (наприклад, перехід 3 фа-дієз-мінору в ре-дієз-мінор або до-мінор).

Частина 2. Sarabande - Lento nostalgico також складається з двох розділів. Їі тривалість - 5:52. Темп § 60.

Друга частина Концерту явно апелює до музичного колориту імпресіоністської музики, і зокрема - до музики М. Равеля, що підкреслено не лише оркестровим колоритом, але й програмним підзаголовком («Сарабанда»), що викликає в пам’яті знамениту «Павану» французького композитора-імпресіоніста. Схожість 3 равелівською музикою підтверджує і трьохдольна ритміка в дуже повільному темпі, яка $\epsilon$ «остинатним» елементом другої частини. Також музика повільної частини Концерту П. Дюбуа близька за своїм образно-мелодійним колоритом до фрагментів саксофонного solo в «Симфонічних танцях» С. Рахманінова, в яких російська народнопісенна мелодика позначена оригінальним тембровим колоритом. Діатонічна мелодія, побудована на пісенному інтонаційному комплексі - в основі якого терцово-квінтовий ладовий приклад - становить основний тематизм другої частини. Розгортання цього джерельного комплексу спрямоване на його мелодико-інтонаційне ускладнення, відхід від пісенності в бік декламаційності. Партія саксофона тут також має яскраво виражений монологічний характер висловлювання, але не в експресивному ключі сонатного алегро, а в ліричному плані. Перед виконавцем, виходячи з цього, стоїть першочергове завдання: передати темброву «теплоту» та «оксамитовість» звучання саксофона, розкрити його темброве розмаїття і красу.

Основна тема втілює співучість, мелодизм. Композитор ставить перед виконавцем складне завдання, що вимагає високорозвиненої 
техніки дихання музиканта: матеріал побудований на довгих безперервних фразах (деякі з них мають тривалість 4 такти й більш в повільному темпі). Їх слід виконувати 3 посиленням і зменшенням динамічного нюансу, при цьому не брати проміжне дихання, щоб не розірвати фразу й не порушити смислову лінію. Інтерес викликають тональні співвідношення, наприклад, в цифрі 5 спостерігається мажорно-мінорний перехід. У цифрі 7 у струнного оркестру проводиться основна тема, а в партії саксофона в цей час проводиться акомпанемент - хроматичні пасажі секстолямі шістнадцятими. Наступне проведення основної теми на саксофоні звучить в соль-дієз-мінорі та на октаву вище початкового викладу теми. Кульмінація частини відбувається в такті 6 цифри 9, в якій саксофон виконує пощаблевий висхідний рух до «фа» третьої октави, гранично високий регістр для цього інструмента, після чого слідує такий же пощаблевий «спуск». У подібних ситуаціях на саксофоні дуже складно досягти м'якого звучання, плавності у виконанні штриха «легато» і непомітної подачі дихання, а також уникнути побічних немузичних звуків, пов'язаних зі стуком клапанів при зміні аплікатури. Закінчення частини - відзвуки фа-дієз-мінорного тризвуку з основної тональності. Останній фрагмент теми має збільшення. I справжнє випробування для амбушюра духовика - фінальна нота «фа-дієз» третьої октави, яку слід виконувати в мінімальному динамічному нюансі - pp.

У другій частині концерту для саксофона варта уваги здійснена автором жанрова трансформація: історично сформований танець сарабанда перетворюється на пісню. Про це можна зробити висновок 3 наявності ознак пісенних витоків: довгих фраз, плавності інтервальних переходів, переважного використання штриха «легато». Хоча розмір $3 / 4$ досить характерний для танцювальних жанрів. Широкі, довгі фрази вступають у протиріччя з танцювальним жанром, якому притаманні чіткість і конкретика рухів. Велику увагу автор приділяє нюансуванню: один і той самий музичний фрагмент при повторенні ніколи не виконується за допомогою однакових динамічних відтінків. Загальна структура повільної частини «скріплена» остинатною ритмікою оркестру, яка $є$ ритмічною «основою» для гармонійного «оздоблення» музичної тканини, що відтворює певні імпресіоніст- 
ські принципи (тональні зіставлення, «стрічковий» рух паралельними акордами тощо).

Частина 3. Rondo - Allegretto має тривалість 4:33. Темп $\delta 138$, розмір $2 / 4$.

Фінал Концерту написаний у традиційній формі рондо, що позначено автором в підзаголовку («Рондо»), і відтворює схему заключної частини класичного сонатно-симфонічного циклу, побудованого на розвитку танцювальної музики. В цьому плані П. Дюбуа дотримується типових норм образно-інтонаційних контрастів, вироблених класичною традицією. Рефрен - яскраво виражена танцювальна музика $з$ опорою на хоровод (із французького музичного фольклору), розвиток матеріалу в епізодах побудовано на відмінностях інтонацій з основного тематизму та його фактурно-гармонійному й ритмічному перетворенні - тобто мотивній розробці. Класична форма рондо послідовно дотримана, але, крім проведення рефрену в цілому вигляді (він зустрічається шість разів протягом третьої частини), музична тканина просякнута окремими фрагментами рефрену. Композитор вдається до прийому «дроблення» фрази на менші складники, а потім використовує їх у різних комбінаціях і в різних тональностях. Ймовірно, це прийшло $з$ практики джазової імпровізації, в якій подібні прийоми набули широкого поширення.

Рефрен починається із затакту в сі-мажор і триває 4 такти. Він являє собою послідовність семи угруповань шістнадцятими. Музичний матеріал між рефренами містить довгі фрази, що виконуються на легато і займають по 8 тактів, а також хроматичні спадні секвенції. Зустрічаються і складні пасажі зі стрибками на широкі інтервали і штрихом стаккато, що ще більше ускладнює виконавське завдання. Щоб досягти рівного й невимушеного звучання, від виконавця вимагається високий технічний рівень підготовки, оскільки при великих інтервальних стрибках за рахунок підвищення регістра, верхні ноти на духовому інструменті звучать голосніше. Таким чином, динаміка й характер звуковидобування мають виявлятися та розподілятися рівномірно. Мотив рефрену може варіюватися доволі непередбачуваним чином. Наприклад, може змінюватися напрямок руху угруповань шістнадцятих, або в середині фрази може з'явитися новий компонент. 
У цифрі 9 звучить новий епізод, який триває до цифри 12. Він включає в себе 7 фраз, що характеризуються хроматичним пощаблевим рухом восьмими по черзі у висхідному і низхідному напрямках. Це в цілому характерно для творчості П. Дюбуа, при цьому композитор може використовувати будь-які складові елементи основних тем, з будь-якими тривалостями та ритмічними малюнками. Часто також можна виявити пасажі, що складаються з терцій, як діатонічних, так і хроматичних.

Переважним штрихом в концерті $є$ легато, але зустрічаються і стаккатні звукові послідовності. Характерною рисою творчості П. Дюбуа є розподіл тривалостей в пасажах, 3 подальшим їх скороченням і збільшенням загальної кількості нот. Важливо відзначити також підхід композитора до динамічних відтінків: від гри у високому регістрі на піанісимо виконавцеві слід починати висхідний пасаж на форте i, в міру переходу до верхніх регістрів, зменшувати динаміку, доводити іiі нарешті до самого тихого динамічного нюансу. Треба врахувати, що це не є властивим для виконавства на духових інструментах. Після середнього епізоду, в якому створюється відчуття уповільнення темпу через перехід на більші тривалості, перед цифрою 21 знову з'являється рефрен, при чому проводиться він у струнних інструментів, в той час, як в інших проведеннях рефрен виконує саксофон. Завершується третя частина (і весь концерт) в тональності сі-мажор, незважаючи на заявлену загальну тональність концерту фа-дієз-мінор.

Підсумовуючи, наведемо твердження Т. Золозової, згідно з яким «... інструментально-симфонічні жанри в післявоєнні роки утримують свою провідну роль як у плані збереження й оновлення багатих традицій, так і в плані новаторських пошуків - модифікацій виразних засобів, еволюції та метаморфоз жанрів. Константними залишаються традиційні ознаки французького інструменталізму - програмність, театральність, жанровість, збагачення музичної мови за рахунок інонаціональних музичних культур, прагнення до мальовничості тембрової палітри, до вишуканих і складних ритмів...» [с. 202].

Висновки дослідження. 3 точки зору виконавства твори для саксофона П. Дюбуа мають незаперечні переваги. Вони інструментальні по самій своїй суті, написані з урахуванням інструментальної специ- 
фіки, хоча й не позбавлені труднощів технічного та образного порядку. Узагальнюючи аналіз Концерту для саксофона П. Дюбуа, можна стверджувати, що цей твір з усією очевидністю «вписується» в художній контекст розвитку французької музики другої половини XX століття, оскільки віддзеркалює процес синтезування різних стильових комплексів в оригінальній авторській концепції.

1. Концерт для саксофона і струнного оркестру П. Дюбуа є оригінальною інтерпретацію концертного жанру в контексті французької музичної культури другої половини XX століття. Зберігаючи національні традиції інструментального мислення - програмність, жанровість, барвистість тембрової палітри - П. Дюбуа значно збагачує музичну мову свого твору й досить вільно трактує композиційну структуру концерту (йдеться про співвідношення розділів форми, їх масштаби, каденцію на самому початку сонатного алегро, «зняту» контрастність тематизму й відхід від конфліктної драматургії). В цілому можна говорити про відхід від сонатності та про пріоритет варіативного розвитку музичного тематизму.

2. Досліджуючи стильові витоки музики Концерту, робимо висновок про звернення композитора до художніх засад таких музичних напрямів як неокласицизм, імпресіонізм, символізм та експресіонізм. При чому кожен із зазначених стильових комплексів немов персоніфікується в конкретній авторській «манері», викликаючи ремінісценції з музикою Д. Шостаковича, С. Рахманінова, П. Гіндеміта, М. Равеля. Подібна «багатовекторність» стильового характеру Концерту зумовлює багатоплановість музичної мови твору і ставить перед виконавцем завдання диференціації виразних засобів - насамперед, тембрової палітри та артикуляційної техніки.

Перспектива подалышого дослідження теми пов'язана з виконавським аналізом інших творів для саксофона П. Дюбуа, порівнянням інтерпретацій, які здійснені сучасними видатними виконавцями.

\section{ЛІТЕРАТУРА}

1. Василевич, Ю. Методичні основи навчання гри на саксофоні // Науковий вісник : зб. статей. К. : НМАУ імені П. І. Чайковського ; упор. М. Давидов, В. Сумарокова, 2008. Вип. 77, кн. 14. С. 202-213. 
2. Золозова, Т. Инструментальная музыка послевоенной Франции (1945-1970). К. : Музична Україна, 1989. 216 с.

3. Иванов, В. Современное искусство игры на саксофоне: проблемы истории, теории и практики исполнительства: автореф. дис. ... д-ра искусствоведения: спец. 17.00.03 - Музыкальное искусство. М., 1997. 40 с.

4. Крупей, М. Стильові основи формування виконавської майстерності саксофоніста (у контексті музичної творчості XIX-XX століть): автореф. дис. ... канд. мистецтвознавства: 17.00.03 - Музичне мистецтво. Одеса, 2006. 15 c.

5. Мимрик, М. Жанрові особливості української камерно-інструментальної музики з участю саксофона кінця XX-XXI століть // Науковий вісник НМАУ імені П. І. Чайковського: Проблеми методики та виконавства на духових інструментах (вокальне та інструментально-духове мистецтво) / Ред.-упорядн.: В. Т. Посвалюк, В. М. Сніжко. К. : НМАУ, 2009. Вип. 83. C. $140-148$.

6. Понькина, А. Саксофон в музыкальной культуре XX века (на материале сонатного творчества зарубежных и украинских композиторов) : дис. ... канд. искусствоведения : 17.00 .03 - музыкальное искусство. Харьков, 2009. $257 \mathrm{c}$.

7. Чуриков, В. Основы исполнительской техники при игре на саксофоне : учеб.-метод. пособие. Харьков, 1996. 25 с.

8. Чуріков, В. Методика навчання гри на музичних інструментах у системі підготовки вчителя музики. К., 1997. 72 с.

9. Dubois Pierre-Max. URL : https://en.wikipedia.org/wiki/Pierre-Max_Dubois

\section{REFERENCES}

1. Vasilevich, Yu. Metodichni osnovi navchannya gri na saksofoni [Methodical basics of playing the saxophone] // Naukovij visnik : zb. statej. K. : NMAU imeni P. I. Chajkovs'kogo ; upor. M. Davidov, V. Sumarokova, 2008. Vip. 77, kn. 14. S. 202-213 [in Ukrainian].

2. Zolozova, T. Instrumental'naya muzyka poslevoennoj Francii (1945-1970). [Instrumental music of post-war France (1945-1970)]. K. : Muzichna Ukraina, 1989. 216 s. [in Russian].

3. Ivanov, V. Sovremennoe iskusstvo igry na saksofone: problemy istorii, teorii i praktiki ispolnitel'stva. [The modern art of playing the saxophone: 
problems of history, theory and practice of performance]: avtoref. dis. ... d-ra iskusstvovedeniya: spec. 17.00.03 - Muzykal'noe iskusstvo. M., 1997. $40 \mathrm{~s}$. [in Russian].

4. Krupej, M. Stil'ovi osnovi formuvannya vikonavs'koï majsternosti saksofonista (u konteksti muzichnoï tvorchosti XIX-XX stolit'). [Style bases of formation of a saxophonist's performing skill (in the context of musical creativity of XIX-XX centuries)]: avtoref. dis. na zdobuttya nauk. stup. kand. mistectvoznavstva: 17.00.03 - Muzichne mistectvo. Odesa, 2006. 15 s. [in Ukrainian].

5. Mimrik, M. Zhanrovi osoblivosti ukraïns'koï kamerno-instrumental'noï muziki z uchastyu saksofona kincya XX-XXI stolit' [Genre features of Ukrainian chamber-instrumental music with the participation of saxophone of the late XX-XXI centuries] // Naukovij visnik NMAU imeni P. I. Chajkovs'kogo: Problemi metodiki ta vikonavstva na duhovih instrumentah (vokal'ne ta instrumental'no-duhove mistectvo) / Red.-uporyadn.: V. T. Posvalyuk, V. M. Snizhko. K. : NMAU, 2009. Vip. 83. S. 140-148. [in Ukrainian].

6. Pon'kina, A. Saksofon v muzykal'noj kul'ture XX veka (na materiale sonatnogo tvorchestva zarubezhnyh i ukrainskih kompozitorov) [Saxophone in 20th Century Music Culture (Based on Sonata Creativity by Foreign and Ukrainian Composers)]: dis. ... kand. iskusstvovedeniya : 17.00.03 - muzykal'noe iskusstvo. Har'kov, 2009. 257 s. [in Russian].

7. Churikov, V. Osnovy ispolnitel'skoj tekhniki pri igre na saksofone [performing technique when playing saxophone]: ucheb.-metod. posobie. H., 1996. 25 s. [in Russian].

8. Churikov, V. Metodika navchannya gri na muzichnih instrumentah u sistemi pidgotovki vchitelya muziki [Methods of teaching the playing of musical instruments in the system of music teacher training]. K., 1997. $72 \mathrm{~s}$. [in Ukrainian].

9. Dubois Pierre-Max. URL : https://en.wikipedia.org/wiki/Pierre-Max_Dubois

Стаття надійшла до редакиії 27.08.2019 р. 